\title{
A New Approach to the Reduction of Alcohol Content in Red Wines: The Use of High-Power Ultrasounds
}

\author{
María Pilar Martínez-Pérez ${ }^{1}$, Ana Belén Bautista-Ortín ${ }^{1}$, Paula Pérez-Porras ${ }^{1}$, Ricardo Jurado ${ }^{2}$ \\ and Encarna Gómez-Plaza ${ }^{1, * \text { D }}$ \\ 1 Department of Food Science and Technology, Faculty of Veterinary Sciences, University of Murcia, \\ Campus de Espinardo, 30100 Murcia, Spain; mpilar.martinez2@um.es (M.P.M.-P.); anabel@um.es (A.B.B.-O.); \\ paula.perez2@um.es (P.P.-P.) \\ 2 Agrovin, S.A. Av. De los Vinos s/n, Alcázar de San Juan, 13600 Ciudad Real, Spain; rjurado@agrovin.com \\ * Correspondence: encarna.gomez@um.es; Tel.: +34-868887323
}

Received: 28 April 2020; Accepted: 30 May 2020; Published: 2 June 2020

check for updates

\begin{abstract}
Background: To obtain wines with a lower percentage of alcohol, the simplest approach would be an earlier harvest of the grapes. However, this has implications for the wine composition and quality, due to the lack of phenolic maturity that these grapes may present. A technological innovation that could help in this situation could be the use of ultrasound in wineries. Methods: Grapes were harvested with two different ripening levels (25.4 ${ }^{\circ}$ Brix and $29^{\circ}$ Brix), transported to the winery, and vinified. Also, a large-scale high-power ultrasound system was used to treat part of the less mature grapes just after crushing. These grapes were also vinified. The three different vinifications were skin-macerated for 7 days. The wine aroma compounds and physicochemical, chromatic, and sensory characteristics were analyzed at the time of bottling. Results: The wine made with the ultrasound-treated grapes showed very similar characteristics to the wine made with the more mature grapes, especially regarding total phenol and tannin content, but with an alcohol content 15\% lower than the latter. Conclusions: The results indicate that this technology could be applied to grapes to favor the extraction of grape phenolic compounds, even when grape phenolic maturity is not complete, allowing the production of quality wines with a reduced alcohol content.
\end{abstract}

Keywords: ultrasounds; phenolic compounds; color; aroma; sensory analysis; alcohol content; wine

\section{Introduction}

Color is one of the most important quality attributes in red wine. It depends on the phenolic composition of the wine (a composition that does not only affects wine color, but also body and mouthfeel), and therefore, is closely bound to the grape phenolic composition.

Grape phenolic compounds are mainly located in the skin (anthocyanins and tannins) and seeds (tannins), and are extracted to must during the crushing and maceration period. Although some enological techniques may help to extract these compounds [1], this extraction can be seriously limited by the cell walls of the cells where these compounds are located, which form a barrier to their extraction [2]. If these cell walls are not easily broken down, the extraction of the phenolic compounds will be limited. From these observations, the concept of phenolic maturity has appeared at the grape stage, where the skin phenolic content is not only high, but also easily extracted, and seed tannin extraction is reduced due to a lignification of the seed [3]. When grapes are phenolically immature, the skin phenolic compounds are not easily extracted, even when present at high concentration, yet high concentrations of the astringent seed tannins can be present $[4,5]$. This situation changes when phenolic maturity is reached, cell walls are easily degraded, and phenolic compounds are extracted [2]. 
In optimal situations, and when a variety is well adapted to a certain area, technological maturity (the optimal level of sugar content in the grapes for a certain type of wine) and phenolic and aromatic maturity (when grapes have lost vegetal and herbaceous aromas and fruity aromas are expressed) are reached at the same time. However, climate change is exerting a large influence on vine phenology and grape composition [6], and among the most important climate change-related effects is a modification in vine phenology [7]. If vine phenology is moved to earlier dates, due to global warming, this can lead to an asynchronous development of grape composition, with the sugar accumulation being faster than the phenolic compounds synthesis. Consequently, a delay in harvesting in order to allow grapes to reach an optimal aromatic and phenolic maturity may lead to higher berry sugar levels than desired, and therefore higher alcohol content in wines [8].

The issue of high-alcohol wines is a big concern for winemakers, since it has potential implications for wine quality. Ethanol is sensorially important to wine, and is indispensable for the stability, aging, and organoleptic properties of wine [9]—and therefore, wine style. However, a high ethanol concentration may present some technological problems: it can be toxic for yeast cells, and as a result, lead to arrested or sluggish fermentation, as stated by Henderson and Block [10], and as stated by Boulton et al. [11], it could inhibit the malolactic fermentation. From a sensory point of view, it can influence our perceptions of astringency, sourness, flavor, and aroma, as recorded by some authors [12-14], and wines can be perceived as hotter on the palate [15]. Lastly but not least importantly, high alcohol content has negative effect on human health and can be more expensive, since they are taxed at higher rates in many countries [16].

Given all these issues, winemakers are really seeking different possibilities for obtaining high quality wines with a reduced alcohol content. Different approaches to reduce alcohol levels in wines have been proposed at all stages of the winemaking process, from the addition of unripe grape juice to finished wines $[17,18]$, to the use of yeasts that have a low production of alcohol $[19,20]$, or the use of technologies for partial dealcoholizing processes [21,22].

It could be, though, that one the easier solutions for wine alcohol reduction would be harvesting grapes with lower sugar content-if we can solve the problem of the low phenolic maturity that these grapes could present at this stage, and therefore, the difficulties in obtaining highly colored wines. Some enological techniques are focused in this issue, such as the use of maceration enzymes or prefermentative maceration techniques, as reviewed by Sacchi et al. [1], as well as novel technologies that could be used to solve this problem.

Among the novel technologies, high-power ultrasounds (HPUs) could be an interesting approach. This is a technology that has already been approved by the International Organization of Vine and Wine (OIV) in 2019 for its use in wineries. HPUs are generally comprised of frequencies between $20-40 \mathrm{kHz}$, with an energy level high enough to produce acoustic cavitation. This effect consists in the formation of tiny bubbles that grow until they reach a critical size that causes their implosion. During the implosion, remarkably high temperatures (circa $5000 \mathrm{~K}$ ) and pressures (circa $2000 \mathrm{~atm}$ ) are reached [23]. When this implosion occurs near a cell, the resulting forces can break the cell walls, leading to two potential results: in plant cells, it allows the diffusion of the compound located inside them [21], and in the case of a microorganism cell, it may lead to death of the organism itself [24].

Therefore, in enology HPUs could be used to

(a) Improve the extraction of phenolic and aroma compounds from grapes [25-28];

(b) Reduce the use of $\mathrm{SO}_{2}$ by reducing microbial counts. In this way, Gracin et al. [29] found that high power ultrasounds applied in continuous flow showed satisfactory reduction of Brettanomyces yeasts (89.1-99.7\%) and lactic acid bacteria (71.8-99.3\%), and Santos et al. [30] review the possibility of using ultrasounds in several stages of winemaking for wine conservation;

(c) Age wines on lees: Kulkarni et al. [31] used non-Saccharomyces strains coupled with ultrasound treatment to accelerate aging on lees, and studied their impacts on the polysaccharide release and on the organoleptic properties of red wine. Cacciola et al. [32] tested the effects of HPUs during wine aging on lees, and found that their effect could be compared with the use of 
$\beta$-glucanases, enzymes which are able to demolish the lees glucans and facilitate the release of intracellular components;

(d) Recover byproducts, such as phenolics from grape pomace [33-35] or stilbenes from grape canes [36];

(e) Accelerate the reactions of aging: one other effect of cavitation is the production of highly reactive radical species, such as $-\mathrm{OH}$ and $-\mathrm{H}$ radicals, that may undergo a range of subsequent reactions, including the generation of $\mathrm{H}_{2} \mathrm{O}_{2}$, and these highly oxidizing species can have a significant effect on both biological and chemical species in aqueous solution [29]. The possible formation of free radicals could help accelerate wine aging reactions [37]. In this way, Zhang et al. [38] have provided the first direct evidence of the formation of the 1-hydroxylethyl free radical (a radical that arises from ethanol oxidation) in red wine exposed to ultrasounds. Lukic et al. [39] has stated that ultrasound treatment might accelerate some aging reactions and shorten the period of wine aging. Zhang and Wang [40] have stated that the ultrasound application did not only temporally influence the color characteristics and phenolic composition of wine, but it also has a longer effect on their evolution during wine storage.

In this work, the interest is focused on the effect that HPUs may have on facilitating the reduction of alcohol content of highly colored wines by the application of those HPUs to crushed grapes with lower sugar content.

\section{Materials and Methods}

\subsection{Grapes}

Monastrell red grapes were all harvested from one vineyard in the province of Murcia (Spain). The vineyard presented two differentiated areas with different maturation stages by a given date. Two separate harvests were done in these two areas, so we had two different batches of grapes from the same vineyard that differed in sugar content. Grapes were transported on the same day to the winery for their processing.

\subsection{Winemaking (Micro-Vinification)}

The less mature grapes ( $400 \mathrm{~kg}, 25.4^{\circ}$ Brix, $14^{\circ}$ Baumé) were destemmed and crushed. Half of the crushed grapes were treated (sonicated vinification, US14) with a winery scale power ultrasound system (MiniPerseo, Agrovin S.A., Alcazar de San Juan, Spain) that can treat $400 \mathrm{~kg}$ of crushed grapes per hour. The system operated at $2500 \mathrm{~W}$ and $28 \mathrm{kHz}$ frequency, with a power density of $8 \mathrm{~W} / \mathrm{cm}^{2}$. The other half of the crushed grapes was not treated (control vinification, C14). The more mature grapes $\left(200 \mathrm{~kg}, 29^{\circ}\right.$ Brix, $16^{\circ}$ Baumé) were also destemmed and crushed (control vinification, C16). Small $50 \mathrm{~kg}$, stainless steel tanks (per triplicate) were filled with both control grapes and with the ultrasound-treated crushed grapes. Must homogeneity in each tank was achieved by weighing the solid parts and the liquid must separately, and filling each $50 \mathrm{~L}$ vessel with the same quantity and proportion to assure the same solid/liquid ratio in each vessel. Total acidity was corrected, if necessary, to $5.5 \mathrm{~g} / \mathrm{L}$, and selected yeasts were added (Viniferm CT007, Agrovin, Alcazar de San Juan, Spain, $20 \mathrm{~g}$ of dry yeast $/ 100 \mathrm{~kg}$ of grapes). The skin maceration time was 7 days for all the samples. Throughout the fermentation pomace contact period, the cap was punched down twice a day. At the end of this period, the wines were pressed in a $75 \mathrm{~L}$ pneumatic press. Free-run and press wines were combined and left at room temperature until the end of alcoholic fermentation. When the fermentation was finished, the wines were racked twice, cold stabilized at $2{ }^{\circ} \mathrm{C}$ for one month, and bottled. They were analyzed at the time of bottling. 


\subsection{Analytical Determinations}

The wines were characterized by measuring the alcohol content, $\mathrm{pH}$, total and volatile acidity, and acetic acid, according to European Community methods [41]. Total and reducing sugars, methanol, malic and tartaric acids, ethanal, and gluconic acid were determined by enzymatic methods carried out via an automated analyzer (Miura One, TDI, Barcelona, Spain).

Spectrophotometric parameters: color intensity (CI) was calculated as the sum of absorbance at 620,520 , and $420 \mathrm{~nm}$, and hue as the ratio between absorbance at $420 \mathrm{~nm}$ and absorbance at $520 \mathrm{~nm}$. Total and polymeric anthocyanins were determined spectrophotometrically [42]. Total phenol index (TPI) were calculated by measuring wine absorbance at $280 \mathrm{~nm}$, according to Ribereau-Gayon et al. [43]. Total tannins were determined by the methyl cellulose precipitation method [44].

Determination of tannins by the phloroglucinolysis method: Wine samples were prepared as described by Busse-Valverde et al. [45] from an optimization of the method described by Pastor del Rio and Kennedy [46]. In short, $5 \mathrm{~mL}$ of wine were evaporated in a centrivap concentrator (Labconco, Kansas City, MO, United States), dissolved in $3 \mathrm{~mL}$ of water, and then passed through a C18-SPE column ( $1 \mathrm{~g}$, Waters, Milford, MA, United States). Compounds of interest were eluted with $10 \mathrm{~mL}$ of methanol, evaporated, and then dissolved in $1 \mathrm{~mL}$ of methanol. The analyses of tannins were done by depolymerizing the molecule using the phloroglucinol reagent. The depolymerized samples (10 $\mu \mathrm{L}$ injection volume) were analyzed by HPLC [45]. These analyses allowed determination of the total tannin content, the apparent mean degree of polymerization (mDP), and the percentage of each constitutive unit. Wine tannin mass conversion yield was also calculated to be $38.16 \% \pm 5.70 \%$.

\subsection{Determination of Wine Volatile Compounds by Solid-Phase Microextraction-Gas Chromatography-Mass Spectrometry (SPME-GC-MS)}

For the isolation of major volatile compounds by solid-phase microextraction (SPME), a divinylbenzene-carboxen-polydimethylsiloxane (DVB/CAR/PDMS) fiber was used. It was conditioned before the first use by insertion into the gas chromatograph injector, as recommended by the manufacturer.

For the analysis of wine volatile compounds, $10 \mathrm{~mL}$ of wine were added to a $20 \mathrm{~mL}$ headspace vial. Four grams of sodium chloride and $50 \mu \mathrm{L}$ of the internal standard $(125 \mu \mathrm{L} / \mathrm{L}$ of 2 -octanol in absolute ethanol) were added to the same vial. The vial was sealed and loaded onto a Gerstel auto-sampling device (Gerstel GmbH and Co.KG, Mellinghofen, Germany), and the analysis was conducted using an Agilent 6890N gas chromatograph coupled to an Agilent 7890B single quadrupole mass spectrometer (Agilent Technologies, Santa Clara, CA, United States). The conditions of the microextraction procedure, the gas chromatograph, and the mass spectra conditions can be found in Gómez-Plaza et al. [47]. Peak identification was carried out by comparing mass spectra with those of the mass library (Wiley 6.0), and also by comparing the calculated Kovats retention indices, determined with reference to a homologous standard series of C9-C30 hydrocarbons, with those published in the literature. Semiquantitative data were obtained by calculating the relative peak area (or total ion signal) in relation to that of the internal standard (2-octanol).

\subsection{Sensory Analysis}

Wines were subjected to sensory evaluation using a descriptive test. Prior to the sensory analysis, the wine from the three different replications for each experience was pooled to have a representative sample, and to avoid differences among the replications. Ten staff members with experience in wine sensory analysis and interest in the project were selected for the sensory analysis.

Forty $\mathrm{mL}$ of each wine was poured $30 \mathrm{~min}$ before evaluation. Glasses were coded and presented to judges in a sensory room that was kept at $20^{\circ} \mathrm{C}$ and free of unusual odors. Each panelist sat in an individual isolated booth illuminated with white light. The intensity of each attribute was rated on a scale of zero to five, with a score of zero indicating that the descriptor was not perceived. Data from all the judges for all samples were used in the analysis. 


\subsection{Statistical Analysis}

The analysis of variance and the principal component analysis were carried out using the statistical package Statgraphics Centurion XVI.3 (Statpoint Technologies, Inc., The Plains, VA, USA).

\section{Results}

Many of the studies about the characteristics of wines made from grapes with different ripening degrees were done on grapes sampled at different times during ripening. However, it is also well known that, at any given point, the physiological characteristics of grape berries in a vineyard are very heterogeneous [48]. This is especially true in large vineyards, where large changes in vineyard orientation or slope or altitude can be found. Based on that, a separate sampling of two different zones of the same vineyard gave us the opportunity of working with grapes grown under the same conditions but with different ripening stages at harvest time.

Table 1 shows the physico-chemical characteristics of the three studied wines. It is important to point out that the system used in this study differs from those used in previous studies, where HPUs have been applied during wine elaboration, since almost all of them used laboratory scale systems, either ultrasonic baths or probes, whereas in this study a winery scale system with a continuous on-line must treatment has been used.

When comparing C14 with US14, no significant differences were found in any of the physico-chemical properties, except for the content in methanol. Methanol is produced before and during alcoholic fermentation from the hydrolysis of pectins by pectinase enzymes (such as pectin methylesterase), which are naturally present in the fruit. More methanol is produced when must is fermented on grape skins; hence, there is generally more methanol in red wines than in rosé or white wines [49]. The higher degree of degradation that ultrasounds caused in grape skins could have increased the concentration of pectins in the must, and the consequent degradation of these pectins may have increased the concentration of methanol in the US14 wine. However, the concentration was lower than the maximum established by the OIV ( $400 \mathrm{mg} / \mathrm{L})$. Zhang et al. [50] also found that HPUs did not affect most of the physico-chemical characteristics of wines.

If we compared the C14 and US14 with C16, the differences were as expected. The alcohol content of $\mathrm{C} 16$ was almost two units higher than C14 and US14. Differences in residual sugars and $\mathrm{pH}$ were small, but total acidity and volatile acidity was higher in C16, with no differences in tartaric acid content (acidity was corrected in the must when necessary). Gluconic acid increased in the wines made from the more mature grapes. Gluconic acid is a product originated by fungi, such as Botrytis cinereainereal, Penicillium, Aspergillus, and Mucor, and bacteria, such as Acetobacter and Gluconobacter, and their presence in must and wines is related to the level of grape infection, which is facilitated by climatic factors like moisture and rainfall, as well as by physiological factors like ripening stage [51]. Therefore, detection of gluconic acid allows estimation of the health status of the grape harvest and wine quality within the production cycle at a winery. OIV stated that levels of gluconic acid of $200-300 \mathrm{mg} / \mathrm{L}$ or lower indicates sound grapes, whereas levels up to $1.0 \mathrm{~g} / \mathrm{L}$ indicate an initial stage of fungus infection [52]. The maximum level detected in our wines was $0.34 \mathrm{~g} / \mathrm{L}$ in $\mathrm{C} 16$ wine.

Ethanal was also controlled to determine if the use of HPUs at the beginning of the winemaking process could, somehow, affect the evolution of vinification and the presence of oxidation markers.

This molecule is produced by ethanol oxidation and although it may, at low concentrations, contribute to red wine color evolution during aging [53], an excessive production of acetaldehyde can result in the appearance of oxidation off-flavor [54]. No differences regarding this compound could be detected between C14 and US14 and C16. 
Table 1. Physico-chemical characteristics of the studied wines.

\begin{tabular}{|c|c|c|c|c|c|c|c|c|c|c|c|}
\hline & $\%$ Alc & RS & TS & $\mathrm{pH}$ & Tac & Vac & $\mathrm{MeOH}$ & Mal & Tart & Ethanal & Gluc \\
\hline C14 & $14.7 \pm 0.2 \mathrm{a}$ & $1.8 \pm 0.1 \mathrm{a}$ & $2.4 \pm 0.1 \mathrm{a}$ & $3.7 \pm 0.02 b$ & $5.0 \pm 0.1 \mathrm{a}$ & $0.6 \pm 0.01 a$ & $192.7 \pm 2.5 a$ & $0.8 \pm 0.1 b$ & $1.4 \pm 0.1 \mathrm{a}$ & $55.3 \pm 3.1 \mathrm{a}$ & $0.09 \pm 0.01 \mathrm{a}$ \\
\hline US14 & $14.6 \pm 0.46 a$ & $2.1 \pm 0.1 \mathrm{a}$ & $2.6 \pm 0.1 \mathrm{a}$ & $3.7 \pm 0.01 b$ & $5.1 \pm 0.10 \mathrm{a}$ & $0.6 \pm 0.01 a$ & $261.0 \pm 9.5 c$ & $0.8 \pm 0.1 b$ & $1.5 \pm 0.1 \mathrm{a}$ & $55.3 \pm 9.0 \mathrm{a}$ & $0.10 \pm 0.01 \mathrm{a}$ \\
\hline $\mathrm{C} 16$ & $16.217 \pm 0.1 b$ & $3.4 \pm 0.1 b$ & $4.1 \pm 0 . b$ & $3.6 \pm 0.01 \mathrm{a}$ & $5.7 \pm 0.1 b$ & $0.9 \pm 0.01 b$ & $217.7 \pm 9.7 b$ & $0.5 \pm 0.1 \mathrm{a}$ & $1.4 \pm 0.1 \mathrm{a}$ & $52.7 \pm 3.5 \mathrm{a}$ & $0.34 \pm 0.04 \mathrm{~b}$ \\
\hline
\end{tabular}

\%Alc: alcohol content, RS: reducing sugars (g/L), TS: total sugars (g/L), Tac: Total acidity (g/L), Vac: volatile acidity (g/L), MeOH: methanol content (mg/L), Mal: malic acid (g/L), Tart:

Tartaric acid $(\mathrm{g} / \mathrm{L})$, ethanal $(\mathrm{mg} / \mathrm{L})$, Gluc: Gluconic acid $(\mathrm{g} / \mathrm{L})$. Different letters within the same column indicate significant differences $(p<0.05)$. 
Table 2 shows the chromatic characteristics of the studied wines. When comparing C14 and C16, we can observe a statistically significant increase in color intensity, total phenols, total anthocyanins, polymeric anthocyanins, and total tannins in C16 wine. Previous results from our group [55], studying the physico-chemical and chromatic characteristics of Monastrell grapes harvested at different degree of ripeness, has shown that even when the grapes were harvested at the moment when anthocyanins content was at its maximum, those grapes did not lead to the most intensely colored wines; however, the wines elaborated from grapes harvested three weeks later had better chromatic characteristics and withstood better aging in the bottle. This was due to the fact that the extent of cell wall degradation in overly matured grapes facilitates the extraction of phenolic compounds from skins, coincident with the results found in this study. Also, Perez Magariño and Gonzalez-San José [56] stated that a late harvest led to the highest quality aged wines, due to a more appropriate phenolic composition that led to a higher stability of their color.

Table 2. Chromatic and phenolic characteristics of the studied wines.

\begin{tabular}{ccccccc}
\hline Sample & CI & Hue & TPI & TAnt & PolAnt & TT (MC) \\
\hline C14 & $14.34 \pm 0.49 \mathrm{a}$ & $0.54 \pm 0.01 \mathrm{~b}$ & $47.95 \pm 1.12 \mathrm{a}$ & $407.63 \pm 17.70 \mathrm{a}$ & $73.07 \pm 5.18 \mathrm{a}$ & $1444.13 \pm 35.36 \mathrm{a}$ \\
US14 & $17.84 \pm 1.22 \mathrm{~b}$ & $0.56 \pm 0.01 \mathrm{c}$ & $60.46 \pm 3.56 \mathrm{~b}$ & $453.23 \pm 39.42 \mathrm{ab}$ & $98.95 \pm 5.13 \mathrm{~b}$ & $1930.31 \pm 27.42 \mathrm{~b}$ \\
C16 & $17.97 \pm 0.79 \mathrm{~b}$ & $0.53 \pm 0.01 \mathrm{a}$ & $60.57 \pm 1.56 \mathrm{~b}$ & $475.49 \pm 19.65 \mathrm{~b}$ & $92.67 \pm 3.83 \mathrm{~b}$ & $1972.49 \pm 47.60 \mathrm{~b}$ \\
\hline
\end{tabular}

CI: color intensity, TPI: total phenol index, TAnt: total anthocyanins (mg/L), PolAnt: polymeric anthocyanins (mg/L), TT (MC): total tannins (determined by the methylcellulose method, $\mathrm{mg} / \mathrm{L}$ ). Different letters within the same column indicate significant differences $(p<0.05)$.

When comparing the C14 and US14 wine chromatic parameters, the positive effect of the application of HPUs to the crushed grapes was clearly observed, with the US14 wine presenting significantly higher values for all the chromatic parameters measured than the C14 wine, except for total anthocyanins, which did not differ from C14 wine. Moreover, US14 wine did not statistically differ in any chromatic parameter from $\mathrm{C} 16$ wine. Our previous studies in the application of HPUs to crushed grapes have shown the increase in chromatic parameters due to HPUs application and its usefulness for reducing maceration time in wineries [27]. Similarly, Ferraretto and Celotti [57], who also studied the effect of the application of ultrasound to crushed grapes on wine color, demonstrated that the sonicated crushed grapes led to musts and wines with higher polyphenol content, with the extraction of tannins being more favored than that of anthocyanins. El Darra et al. [26] also compared the effect of HPU-treated grapes, using a lab bath, on wine phenolic content, finding an enhancement in the polyphenol content.

Table 3 shows the compositional information of the wine tannins, obtained through a phloroglucinolysis reaction. This methodology not only gives us information on the tannins that can be depolymerized by the phloroglucinol reagent, but also allows us to gain information on the mean degree of polymerization of these tannins and their composition, especially regarding galloylated units and the presence of epigallocatechin subunits. Similarly, to the data observed when tannins were determined by the methyl cellulose method, if we compared both control wines, tannin concentration was higher in $\mathrm{C} 16$ wine than in $\mathrm{C} 14$ wine. This is related with an easier extraction of these compounds from skins, and, in the same way, the concentration of the subunit epigallocatechin (EGC) was slightly higher in C16 wine, although differences were not statistically significant. EGC is a subunit that only can arise from grape skins, where both prodelphinidins and procyanidins are present, contrary to seeds, where only procyanidins are present. The mean degree of polymerization of C14 and C16 wines was similar whereas a slightly higher percentage of galloylation was observed in the tannins from C16 wine, a parameter that could indicate a larger extraction of seed tannins in C16 wine, probably due to the higher concentration of alcohol in the medium during fermentation favoring the extraction of these tannins. 
Table 3. Concentration and composition of total tannins determined by the phloroglucinolysis method.

\begin{tabular}{cccccc}
\hline & TT $(\mathbf{m g} / \mathbf{L})$ & mDP & \%Gal & EGC $(\mu \mathbf{M})$ & ECG $(\mu \mathbf{M})$ \\
\hline C14 & $698.22 \pm 21.14 \mathrm{a}$ & $6.21 \pm 0.02 \mathrm{c}$ & $2.74 \pm 0.01 \mathrm{a}$ & $398.11 \pm 27.84 \mathrm{a}$ & $62.22 \pm 11.45 \mathrm{a}$ \\
US14 & $951.47 \pm 46.98 \mathrm{c}$ & $4.91 \pm 0.07 \mathrm{a}$ & $4.16 \pm 0.01 \mathrm{c}$ & $394.25 \pm 31.66 \mathrm{a}$ & $129.71 \pm 17.82 \mathrm{~b}$ \\
C16 & $801.44 \pm 17.12 \mathrm{~b}$ & $6.03 \pm 0.11 \mathrm{~b}$ & $3.12 \pm 0.02 \mathrm{~b}$ & $451.39 \pm 25.51 \mathrm{a}$ & $71.36 \pm 9.53 \mathrm{a}$ \\
\hline
\end{tabular}

When comparing C14 and US14 wine, important differences were observed. The concentration of tannins was much higher in the wine elaborated with sonicated grapes. The lower value of $\mathrm{mDP}$, together with the higher value of epicatechin gallate subunit (ECG) in US14 wine indicated a higher extraction of tannins from seeds. Furthermore, the concentration of EGC was similar in C14 and US14 and the most important difference was the concentration of ECG. Up until now, there are no studies where the effect of HPUS on seed integrity has been reported but the results pointed to an effect of HPUS in the easiness of seed tannin extraction. Comparing US14 and C16 wines, US14 wine presented higher tannin concentration and a lower $\mathrm{mDP}$ than $\mathrm{C} 16$ wine, reiterating the positive effect of HPUS in tannin extraction, which may help to ensure a high wine color stability during storage.

The application of HPU technology to crushed grapes and its effect on the wine's volatile compounds has been less studied than its effect on phenolic compounds. Bautista-Ortin et al. [25] studied the application of HPUS to crushed grapes, looking for a reduction on the maceration time needed for the extraction of phenolic and volatile compounds, and they found only small differences in the wine volatile composition. Roman et al. [58] applied ultrasounds to Sauvignon Blanc crushed grapes, and found an increase in thiol compounds, key aroma compounds for Sauvignon Blanc wines. Zhang et al. [59] also studied the effect of ultrasounds on higher alcohol content in wine, reporting a decrease in these compounds, although they applied the HPUs treatment to finished wines to study their evolution during aging and not to crushed grapes.

Table 4 shows how the level of maturity in grapes and the use of HPUs affected the major volatile components of the different wines.

Table 4. Major volatile compounds in the control wines and in the wine from ultrasound-treated grapes ( $\mu \mathrm{g}$ of 2-octanol equivalents/L).

\begin{tabular}{cccc}
\hline & Control 14 & US14 & Control 16 \\
\hline Esters & & & \\
2-Methylpropyl acetate & $1290 \mathrm{a}$ & $1246 \mathrm{a}$ & $2140 \mathrm{~b}$ \\
Ethyl butanoate & $7 \mathrm{a}$ & $9 \mathrm{a}$ & $15 \mathrm{~b}$ \\
Ethyl 2-methylbutanoate & $10 \mathrm{~b}$ & $2 \mathrm{a}$ & $3 \mathrm{~b}$ \\
Ethyl 3-methylbutanoate & $4 \mathrm{~b}$ & $2 \mathrm{a}$ & $4 \mathrm{~b}$ \\
3-Methylbutanol acetate & $316 \mathrm{a}$ & $252 \mathrm{a}$ & $377 \mathrm{~b}$ \\
Ethyl hydrogen succinate & $2 \mathrm{a}$ & $3 \mathrm{a}$ & $5 \mathrm{a}$ \\
Ethyl hexanoate & $440 \mathrm{a}$ & $432 \mathrm{a}$ & $392 \mathrm{a}$ \\
Hexyl acetate & $89 \mathrm{~b}$ & $8 \mathrm{a}$ & $4 \mathrm{a}$ \\
3-Hexenyl acetate & $0 \mathrm{a}$ & $1 \mathrm{~b}$ & $0 \mathrm{a}$ \\
Ethyl heptanoate & $10 \mathrm{a}$ & $13 \mathrm{a}$ & $28 \mathrm{~b}$ \\
Ethyl 2-hexenoate & $15 \mathrm{a}$ & $13 \mathrm{a}$ & $12 \mathrm{a}$ \\
Methyl octanoate & $10 \mathrm{a}$ & $13 \mathrm{a}$ & $11 \mathrm{a}$ \\
Ethyl octanoate & $1760 \mathrm{a}$ & $1672 \mathrm{a}$ & $2049 \mathrm{~b}$ \\
Isopentyl hexanoate & $17 \mathrm{a}$ & $23 \mathrm{~b}$ & $31 \mathrm{c}$ \\
Ethyl decanoate & $1012 \mathrm{a}$ & $1343 \mathrm{~b}$ & $1422 \mathrm{~b}$ \\
3-Methylbutanol octanoate & $36 \mathrm{a}$ & $38 \mathrm{a}$ & $46 \mathrm{a}$ \\
\hline
\end{tabular}


Table 4. Cont.

\begin{tabular}{|c|c|c|c|}
\hline & Control 14 & US14 & Control 16 \\
\hline Diethyl succinate & $36 a$ & $32 a$ & $44 \mathrm{~b}$ \\
\hline Ethyl 9-decenoate & $30 \mathrm{~b}$ & $14 a$ & $19 a$ \\
\hline Ethyl undecanoate & $25 b$ & $13 a$ & $20 \mathrm{~b}$ \\
\hline 2-Phenylethyl acetate & $115 b$ & $80 a$ & $118 b$ \\
\hline Ethyl dodecanoate & $144 \mathrm{a}$ & $251 b$ & $244 b$ \\
\hline Pentyl decanoate & $25 a$ & $28 a$ & $32 a$ \\
\hline \multicolumn{4}{|l|}{ Alcohols } \\
\hline Propanol & $0 \mathrm{a}$ & $2 b$ & $2 b$ \\
\hline 2-Methylpropanol & $146 \mathrm{~b}$ & $115 a$ & $161 b$ \\
\hline Butanol & $1 \mathrm{a}$ & $4 b$ & $8 c$ \\
\hline 3-Methylbutanol & $2181 \mathrm{a}$ & $2048 a$ & $3066 b$ \\
\hline 4-Methylpentanol & 1a & $1 \mathrm{a}$ & $3 b$ \\
\hline 3-Methylpentanol & $4 a$ & $3 a$ & $6 b$ \\
\hline Hexanol & $95 b$ & $119 \mathrm{c}$ & $75 a$ \\
\hline Heptanol & $22 c$ & $82 a$ & $13 b$ \\
\hline 2-Ethylhexanol & $8 a$ & $27 \mathrm{c}$ & $13 b$ \\
\hline Octanol & $15 a$ & $17 \mathrm{a}$ & $21 b$ \\
\hline 2,3-Butanediol & $26 a$ & $22 \mathrm{a}$ & $42.22 b$ \\
\hline Methyl thiopropanol & $18 \mathrm{a}$ & $12 \mathrm{a}$ & $2 a$ \\
\hline Benzyl alcohol & $26 b$ & $0 \mathrm{a}$ & $0 \mathrm{a}$ \\
\hline 2-Phenylethanol & $1849 b$ & $1457 \mathrm{a}$ & $2324 c$ \\
\hline Sum alcohols & $4393 a$ & $3836 a$ & $5734 b$ \\
\hline \multicolumn{4}{|c|}{ Carbonyl compounds and lactones } \\
\hline 2-Octanone & $8 a$ & $11 b$ & $8 a$ \\
\hline Benzaldehyde & $13 a$ & $16 \mathrm{a}$ & $20 b$ \\
\hline 3-Hydroxy-2-butanone & $84 a$ & $82 a$ & $169 \mathrm{~b}$ \\
\hline$\gamma$-Butyrolactone & $6 \mathrm{~b}$ & $0 \mathrm{a}$ & $12 \mathrm{c}$ \\
\hline \multicolumn{3}{|l|}{ Acids } & $209 b$ \\
\hline Acetic acid & $106 a$ & $81 \mathrm{a}$ & $164 b$ \\
\hline Propanoic acid & $7 \mathrm{~b}$ & $14 \mathrm{~b}$ & $0 \mathrm{a}$ \\
\hline Butanoic acid & $34 a$ & $10 \mathrm{a}$ & $30 \mathrm{a}$ \\
\hline Hexanoic acid & $73 b$ & $27 \mathrm{a}$ & $21 \mathrm{a}$ \\
\hline Octanoic acid & $161 b$ & $72 a$ & $43 a$ \\
\hline Sum acids & $380 \mathrm{~b}$ & $205 a$ & $258 \mathrm{a}$ \\
\hline \multicolumn{4}{|l|}{ Terpens and norisoprenoids } \\
\hline Limonene & $6 a$ & $4 a$ & $4 a$ \\
\hline Terpinolene & $9 a$ & $6 a$ & $3 a$ \\
\hline$(+)$-cis-m-Menth-8-en & $18 \mathrm{~b}$ & $14 \mathrm{~b}$ & $0 \mathrm{a}$ \\
\hline$\beta$-Ionone & $65 b$ & $12 \mathrm{a}$ & $20 a$ \\
\hline Linalool & $17 \mathrm{a}$ & $16 a$ & $40 \mathrm{~b}$ \\
\hline Terpinen-4-ol & $3 b$ & $0 \mathrm{a}$ & $0 \mathrm{a}$ \\
\hline Citronellol & $71 b$ & $27 \mathrm{a}$ & $17 \mathrm{a}$ \\
\hline Sum & $189 \mathrm{~b}$ & $80 a$ & $83 a$ \\
\hline
\end{tabular}

Different letters within the same row indicate significant differences $(p<0.05)$.

Esters, as one of the most important odorants in wines, provide abundant floral and tropical fruity aromas [60]. The origin of esters in wine is primarily the fermentation process, although they could be present in small amounts in grapes [61]. Two different groups of esters were detected in the wines: the acetates of ethanol and other higher alcohols, and the esters of fatty acid and ethanol. The most abundant esters were isobutyl acetate, isoamyl acetate, ethyl hexanoate, ethyl octanoate, and ethyl decanoate. The majority of them were affected more by grape maturity than by the application of ultrasounds to crushed grapes, which could be expected given the origin of these compounds, and the fact that the ultrasound treatment did not affect the most important must characteristics 
or the development of the fermentation process (data not shown). The increase in sugar content associated with the more mature grapes, and therefore, the higher production of ethanol and higher alcohols were responsible for the higher concentration of acetates in C16 wine compared with C14 wine, although hexyl acetate was present at higher concentration in C14 wine. Similar results were stated by Zhao et al. [60]. Regarding fatty acid esters, previous results have described a large presence of fatty acids, formed via the lipid metabolism of yeast in the more mature musts [62]; this may favor a higher concentration of their esters in wine.

The higher presence of both types of esters implies that the sum of esters was higher in C16 wine. These results were also reported by Bindon et al. [63], who found that extended ripening time was associated with increased concentrations of some esters, such as ethyl decanoate and butyl acetate. The sum of total esters was not significantly different when we compared C14 and US14 wine; only small differences in some esters could be observed, with higher concentrations in ethyl decanoate and dodecanoate found in US14.

The production of higher alcohols is linked to the amino acid metabolism by yeasts, and the alcohol deshydrogenase enzymes in fruit and yeasts are the responsible for catalyzing the reduction of aliphatic aldehydes to alcohols [61]. We found a higher concentration of alcohols in the wine from the more mature grapes, although a decrease in hexanol (leafy, grassy aroma) and heptanol (chemical, green notes) due to higher maturation of the grapes was detected. Benzyl alcohol was not detected in C16 wine, yet 2-phenyl ethanol, with a rose aroma, and octanol were present at higher concentrations in this wine.

Comparing C14 and US14 wine, no difference in the sum of total alcohols could be observed although some differences in individual alcohols were found, such as higher concentrations of 3-methyl-1-butanol, 1-heptanol, or 2-phenylethanol, and lower concentrations of hexanol in C14 wine. Although higher alcohols can contribute to a positive effect on wine aroma if they are not present at very high concentrations [64], Zhang et al. [59] have proposed the use of HPUs to reduce higher alcohol content in finished wines.

Concentrations of linear fatty acids decreased in the wine made with the more mature grapes, except for the concentration of acetic acid, which increased in these wines, as would be expected, because concentrations of sugars also increased. These acids are important in the wine aroma balance, although they may impart an unpleasant fatty odor, and even a rancid smell in wine, when present at high concentrations. Although a higher concentration of fatty acids has been described in must from mature grapes [62], the reduction observed in the wine made from the more mature grapes can be related to the previously observed higher concentration of their corresponding esters. It is clear that a connection between harvest time and concentrations of esters and acids in the wine exists. Studies have shown that the sensory differences observed in Grenache wines made with grapes with different ripening stages could be explained by the variability in the concentration of important major volatile compounds, such as esters and acids [65]. Slightly higher concentrations of fatty acids were measured in C14 wine than in US14 wine; the application of HPUs on crushed grapes led to a modification in these compounds. Restrepo et al. [66] found that anaerobic conditions could favor the accumulation of fatty carboxylic acids, and we hypothesized that, although HPUs may have a degassing effect, the process also implies a higher movement of the crushed grapes and that small amounts of oxygen could be dissolved in the must, justifying the lower amounts of fatty acids in the US14 wine.

Among other compounds, benzaldehyde (almond, burnt sugar notes) can be associated with defective wines [67]. It is probably formed by the oxidation of benzyl alcohol, or by the action of microorganisms on aromatic amino acids [61]. The higher concentration of it in C16 wine may explain the lack of detection of benzyl alcohol in these wines. Terpenes were present at lower concentrations in the wine made from the most mature grapes and in the HPUs-treated grapes, except linalool in C16 wine, where higher concentrations were observed. Curko et al. [68] found that the application of HPUs with the highest amplitude could decrease the quantity of linalool, and García et al. [69] suggested that 
ultrasounds decreased grape aroma in wine, which could be reasonable since most of aromas come from volatile compounds, and may be easily lost by the degassing effect of ultrasound.

The results up to now point to large differences in the phenolic compounds and chromatic characteristics of wine due to the use of ultrasounds in the winery, while variations in wines' volatile compounds were not so evident. However, the most important tool researchers have for evaluating if the observed changes in phenolic and volatile compounds due to ultrasounds will have any effect on consumers' appreciation is the sensory analysis. Wines were subjected to a descriptive sensory analysis, and Figure 1 shows the results of this analysis. It can be seen how with color attributes, color intensity was slightly lower in C14 wine than in C16 and US14 wines, although differences were not significant in either color intensity or tonality among the three wines. On the other hand, significant differences in aroma intensity and quality were observed among wines, with aroma intensity reaching higher scores in C16 wine (probably related to the highest concentration of most of the families of volatile compounds measured in this wine), although aroma quality scored the highest value in US14 wine. Although, as observed previously, C16 wine presented higher concentrations of esters, no differences were observed in fruity aroma, probably because most of these esters could be present at concentrations lower than their odor threshold. Another reason for the higher aroma quality of US14 compared with $\mathrm{C} 16$ wine, together with the similarity in fruity aroma perception (although esters were present at higher concentration in C16 wine), can be attributed to the higher alcoholic content of C16 wine. King et al. [14] found that fresh fruit aroma decreased as the alcohol concentration increased, confirming the results of Goldner et al. [13] that ethanol suppresses "fruity" aromas.

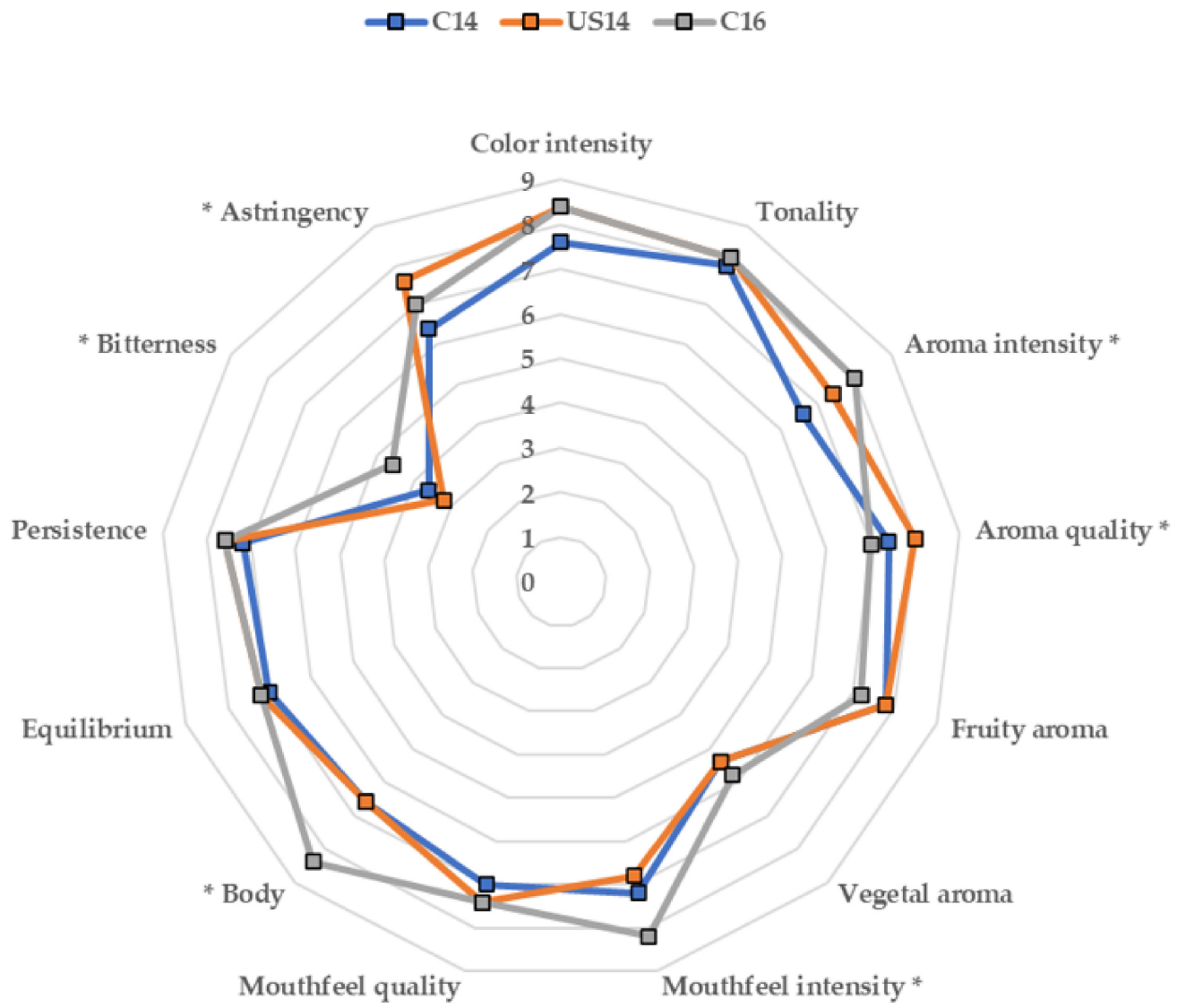

Figure 1. Descriptive sensory analysis of the three different wines $(*$ denotes significant differences $p<0.05)$.

Mouthfeel intensity and body scores were significantly higher in C16 wine (which could be related to its higher alcohol content), and no differences in mouthfeel quality, equilibrium, or persistence 
could be detected among wines. Bitterness was higher in C16 than in C14 or US14. The greater bitter sensation imparted by C16 wine has to be attributed to the higher alcohol content. Noble [70] reported that bitterness in wine is elicited by flavonoid phenols, which are bitter and astringent, but also by ethanol, and that ethanol enhances wine bitterness intensity and duration. Similarly, Cretin et al. [71] found that the sweetness of dry wines was not affected by ethanol content; however, ethanol had an indirect effect on wine taste by increasing the bitterness perception. Astringency was higher in US14 compared to $\mathrm{C} 14$ wine, which is in accordance with the higher concentration of tannins measured in these wines and their higher percentage of galloylation-although that did not differ from the percentage in C16 wine. Previous results showed that delayed-harvest Merlot wines were described as having higher viscosity, sweet taste, and fruit-derived aromas, while early-harvest wines were described by vegetal character, acidity, and low color intensity [64]. In contrast, in Cabernet franc wines, astringency, bitterness, color intensity, and alcohol increased with delayed harvest [72], very similar results to those observed here. The most significative changes that could be attributed to the application of ultrasounds in US14 wine was the higher color and aroma quality and higher astringency.

A principal component analysis was conducted using all the measured chromatic and phenolic parameters, together with the sum of major aroma compounds and sensory scores as variables. This analysis reduced the information provided by all the measured variables to two principal components, and explained $78 \%$ of the variability of the data (Figures 2 and 3). The objective was to find out how the wine samples were grouped, or more exactly, where they were located in the plane defined by the first two principal components, in order to determine how closely the US14 and C16 wine samples were located (which would indicate similarities in their characteristics) and which variables were mainly responsible for the grouping. A clear separation between samples was observed. C14 wine was separated from C16 wine and US14 wine along component 1, while US14 and C16 wines were closely located along component 1 , yet clearly separated along component 2 .

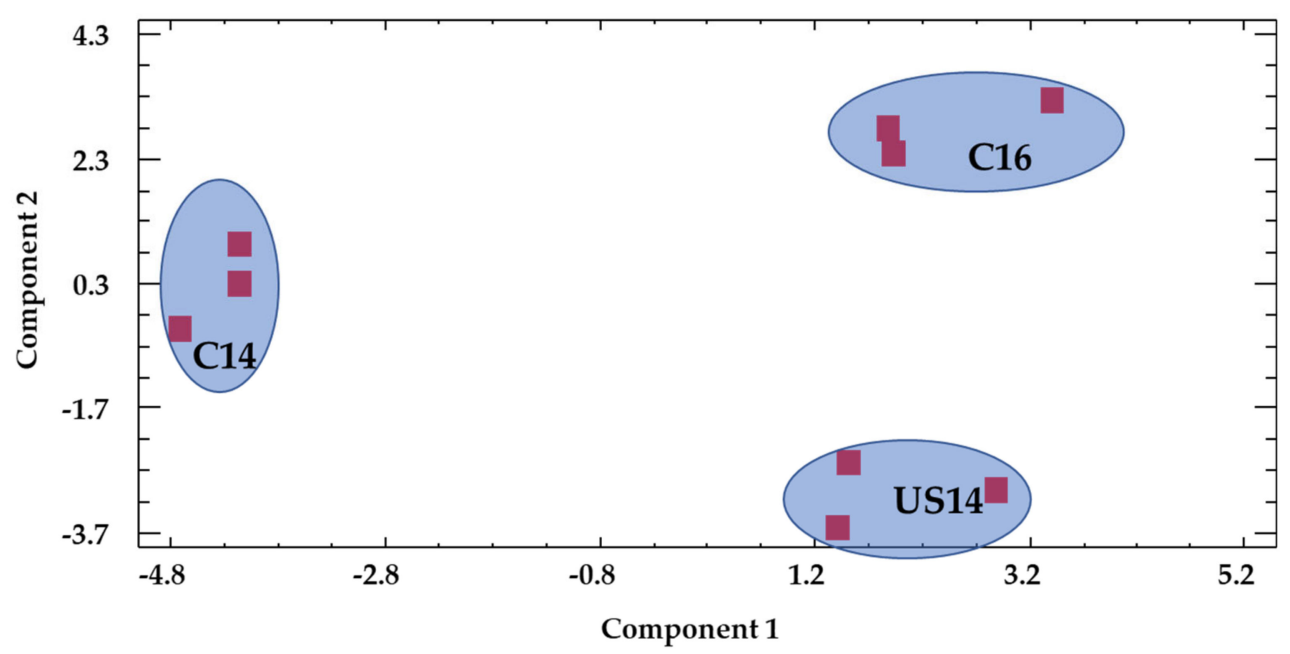

Figure 2. Distribution of the different wine samples in the plane defined by the two first principal components. 


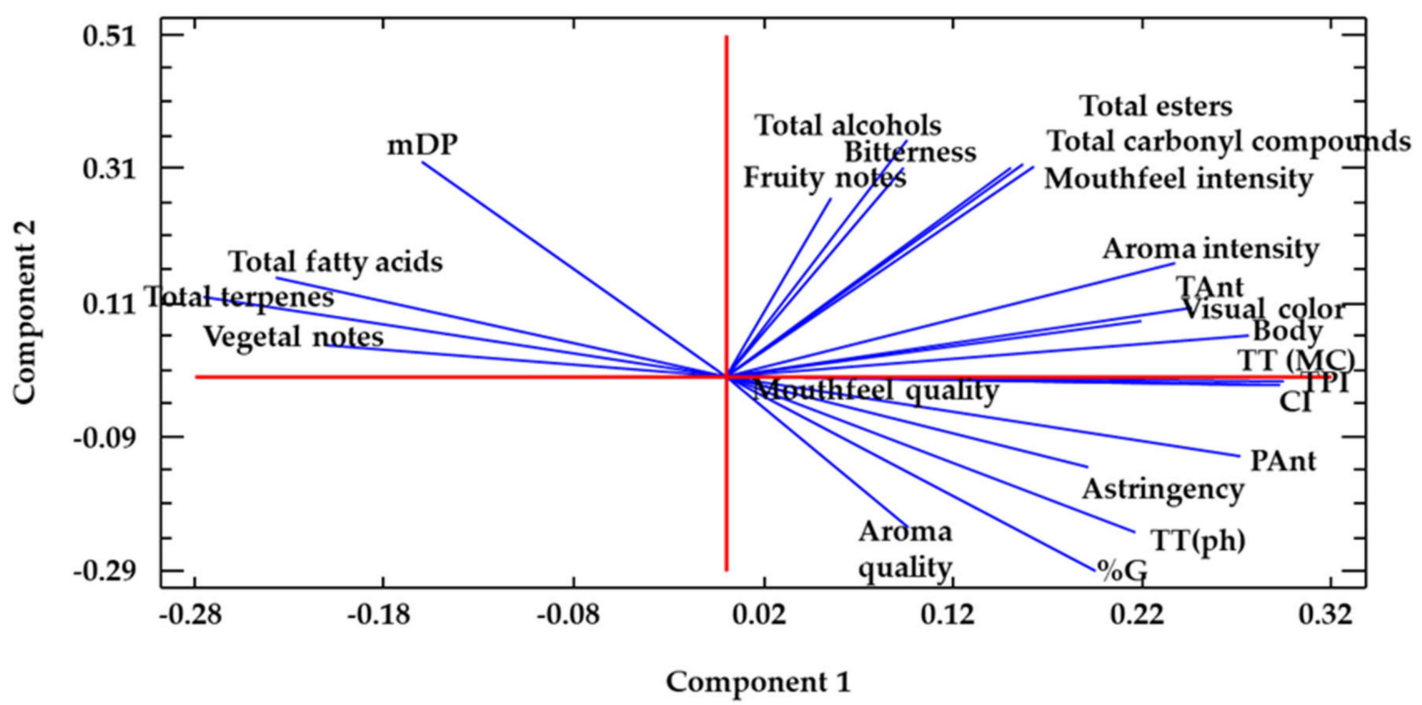

Figure 3. Distribution of the weight of the different variables used in the principal component analysis. CI: color intensity, TPI: total phenol index, TAnt: total anthocyanins, PolAnt: polymeric anthocyanins, TT (MC): total tannins determined by the methylcellulose method, TT(ph): total tannins determined by phloroglucinolysis, \%G: percentage of galloylation, mDP: mean degree of polymerization.

The different weights of the variables in achieving the sample separation can be seen in Figure 3. Those with the highest loadings in the negative part of component 1 , where the C14 wine sample was located, were tannin mDPs, vegetal aroma scores, and two families of volatile compounds (fatty acid content and the concentration of terpenes and norisoprenoids), whereas all the other descriptors were located in the positive part of component 1. US14 wine samples were located in the negative part of component 2, and C16 wine was in the positive part. The descriptors with the highest loadings in the negative part of component 2 were astringency, total tannins (determined by phloroglucinolysis), percentage of galloylation, and the aroma quality, which is quite coincident with the observed results of the analytical variables. This analysis clearly indicates that the use of HPUs induces a modification in the wine composition, especially the chromatic composition and sensory characteristics, leading to a wine that shares more characteristics with the one made with the more mature grapes, while maintaining a lower alcohol content.

\section{Conclusions}

In conclusion, the results showed that the wine obtained with ultrasound-treated grapes presented chromatic characteristics that did not differ to those of a wine obtained from more mature grapes, and reached the highest scores in aroma and mouthfeel quality descriptors in a sensory analysis. The use of ultrasound technology, being a clean, eco-friendly, and energetically very efficient technology-and not less importantly, being an authorized practice in wineries-could be an interesting option for obtaining wines with similar color intensity and sensorial quality parameters as wines obtained from more mature grapes, but with a lower alcohol content.

Author Contributions: Conceptualization, E.G.-P., R.J., and A.B.B.-O.; methodology, A.B.B.-O.; formal analysis, M.P.M.-P. and P.P.-P.; investigation, E.G.-P., R.J., and A.B.B.-O.; data curation, E.G.-P.; writing-original draft preparation, M.P.M.-P. and E.G.-P.; writing-review and editing, E.G.-P., A.B.B.-O. All authors have read and agreed to the published version of the manuscript.

Funding: This research was funded by the Consejería de Empleo, Universidades, Empresa y Medio Ambiente and Feder Funds, grant number 2I18SAE00061.

Conflicts of Interest: The authors declare no conflict of interest. 


\section{References}

1. Sacchi, K.L.; Bisson, L.F.; Adams, D.O. A review of the effect of winemaking techniques on phenolic extraction in red wines. Am. J. Enol. Vitic. 2005, 56, 197-206.

2. Ortega-Regules, A.; Ros-García, J.M.; Bautista-Ortín, A.B.; López-Roca, J.M.; Gómez-Plaza, E. Changes in skin cell wall composition during the maturation of four premium wine grape varieties. J. Sci. Food Agric. 2008, 88, 420-428. [CrossRef]

3. Saint-Cricq de Gaulejac, N.; Vivas, N.; Glories, Y. Maturité phénolique: Définition et contrôle. Rev. Fr. Oenol. 1998, 173, 22-25.

4. Bautista-Ortín, A.B.; Rodríguez-Rodríguez, P.; Gil-Muñoz, R.; Jiménez-Pascual, E.; Busse-Valverde, N.; Martínez-Cutillas, A.; López-Roca, J.M.; Gómez-Plaza, E. Influence of berry ripeness on concentration, qualitative composition and extractability of grape seed tannins. Aust. J. Grape Wine Res. 2012, 18, 123-130. [CrossRef]

5. Rousserie, P.; Lacampagne, S.; Vanbrabant, S.; Rabot, A.; Geny-Denis, L. Influence of berry ripeness on seed tannins extraction in wine. Food Chem. 2020, 315, 126307. [CrossRef]

6. Mira De Orduña, R. Climate change associated effects on grape and wine quality and production. Food Res. Int. 2010, 43, 1844-1855. [CrossRef]

7. Jones, G.V.; Davis, R.E. Climate influences on grapevine phenology, grape composition, and wine production and quality for Bordeaux, France. Am. J. Enol. Vitic. 2000, 51, 249-261.

8. Longo, R.; Blackman, J.W.; Antalick, G.; Torley, P.J.; Rogiers, S.Y.; Schmidtke, L.M. Volatile and sensory profiling of Shiraz wine in response to alcohol management: Comparison of harvest timing versus technological approaches. Food Res. Int. 2018, 109, 561-571. [CrossRef]

9. Jackson, R.S. Wine Science: Principles and Applications, 3rd ed.; Academic Press: San Diego, CA, USA, 2008; pp. 270-331.

10. Henderson, C.M.; Block, D.E. Examining the role of membrane lipid composition in determining the ethanol tolerance of Saccharomyces cerevisiae. Appl. Environ. Microbiol. 2014, 80, 2966-2972. [CrossRef]

11. Boulton, R.B.; Singleton, V.L.; Bisson, L.F.; Kunkee, R.E. Principles and Practices of Winemaking, 1st ed.; Chapman and Hall Publishers: New York, NY, USA, 1996.

12. Wilkinson, K.; Jiranck, V. Wine of reduced alcohol content: Consumer and society demand vs industry willingness and ability to deliver. In Proceedings of the 1st International Symposium on Alcohol Level Reduction in Wine Oenoviti International Network, Bordeaux, France, 6 September 2013; Institut des Sciences de la Vigne et du Vin: Villenave d'Ornon, France, 2013; pp. 98-104.

13. Goldner, C.; Zamora, M.C.; Lira, P.; Gianninoto, H.; Bandoni, A. Effect of ethanol level in the perception of aroma attributes and the detection of volatile compounds in red wine. J. Sens. Stud. 2009, 24, $243-257$. [CrossRef]

14. King, E.; Dunn, R.; Heymann, H. The influence of alcohol on the sensory perception of red wines. Food Qual. Prefer. 2013, 28, 235-243. [CrossRef]

15. Gawel, R.; Sluyter, S.V.; Waters, E.J. The effects of ethanol and glycerol on the body and other sensory characteristics of Riesling wines. Aust. J. Grape Wine Res. 2007, 13, 38-45. [CrossRef]

16. Sharma, A.; Vandenberg, B.; Hollingsworth, B. Minimum pricing of alcohol versus volumetric taxation: Which policy will reduce heavy consumption without adversely affecting light and moderate consumers? PLoS ONE 2014, 9, e80936. [CrossRef] [PubMed]

17. Piccardo, D.; Favre, G.; Pascual, O.; Canals, J.M.; Zamora, F.; González-Neves, G. Influence of the use of unripe grapes to reduce ethanol content and $\mathrm{pH}$ on the color, polyphenol and polysaccharide composition of conventional and hot macerated Pinot Noir and Tannat wines. Eur. Food Res. Technol. 2019, 245, 1321-1335. [CrossRef]

18. Teng, B.; Petrie, P.R.; Smith, P.A.; Bindon, K.A. Comparison of water addition and early-harvest strategies to decrease alcohol concentration in Vitis vinifera cv. Shiraz wine: Impact on wine phenolics, tannin composition and colour properties. Aust. J. Grape Wine Res. 2020, 26, 158-171. [CrossRef]

19. Grazia, A.; Pietrafesa, A.; Capece, A.; Pietrafesa, R.; Siesto, G.; Romano, P. Exploitation of technological variability among wild non-Saccharomyces yeasts to select mixed starters for the production of low alcohol wines. BIO Web Conf. 2019, 15. [CrossRef] 
20. Varela, C.; Kutyna, D.R.; Solomon, M.R.; Black, C.A.; Borneman, A.; Henschke, P.A.; Pretorius, I.S.; Chambers, P.J. Evaluation of gene modification strategies for the development of low-alcohol-wine yeasts. Appl. Environ. Microbiol. 2012, 78, 6068-6077. [CrossRef]

21. Corona, O.; Liguori, L.; Albanese, D.; Di Matteo, M.; Cinquanta, L.; Russo, P. Quality and volatile compounds in red wine at different degrees of dealcoholization by membrane process. Eur. Food Res. Technol. 2019, 245, 2601-2611. [CrossRef]

22. Pham, D.T.; Stockdale, V.J.; Wollan, D.; Jeffery, D.W.; Wilkinson, K.L. Compositional consequences of partial dealcoholization of red wine by reverse osmosis-evaporative perstraction. Molecules 2019, 24, 1404. [CrossRef]

23. Clodoveo, M.L.; Dipalmo, T.; Rizzello, C.G.; Corbo, F.; Crupi, P. Emerging technology to develop novel red winemaking practices: An overview. Innov. Food Sci. Emerg. Technol. 2016, 38, 41-56. [CrossRef]

24. Luo, H.; Schmid, F.; Grbin, P.R.; Jiranek, V. Viability of common wine spoilage organisms after exposure to high power ultrasonics. Ultrason. Sonochem. 2012, 19, 415-420. [CrossRef] [PubMed]

25. Gambacorta, G.; Trani, A.; Punzi, R.; Fasciano, C.; Leo, R.; Fracchiolla, G.; Faccia, M. Impact of ultrasounds on the extraction of polyphenols during winemaking of red grapes cultivars from southern Italy. Innov. Food Sci. Emerg. Technol. 2017, 43, 54-59. [CrossRef]

26. El Darra, N.; Grimi, N.; Maroun, R.G.; Louka, N.; Vorobiev, E. Pulsed electric field, ultrasound, and thermal pretreatments for better phenolic extraction during red fermentation. Eur. Food Res. Technol. 2013, 236, 47-56. [CrossRef]

27. Bautista-Ortín, A.B.; Jiménez-Martínez, M.D.; Jurado, R.; Iniesta, J.A.; Terrades, S.; Andrés, A.; Gómez-Plaza, E. Application of high-power ultrasounds during red wine vinification. Int. J. Food Sci. Technol. 2017, 52, 1314-1323. [CrossRef]

28. Maza, M.; Álvarez, I.; Raso, J. Thermal and non-thermal physical methods for improving polyphenol extraction in red winemaking. Beverages 2019, 5, 47. [CrossRef]

29. Gracin, L.; Jambrak, A.R.; Juretić, H.; Dobrović, S.; Barukčić, I.; Grozdanović, M.; Smoljanić, G. Influence of high power ultrasound on Brettanomyces and lactic acid bacteria in wine in continuous flow treatment. Appl. Acoust. 2016, 103, 143-147. [CrossRef]

30. Santos, M.C.; Nunes, C.; Saraiva, J.A.; Coimbra, M.A. Chemical and physical methodologies for the replacement/reduction of sulfur dioxide use during winemaking: Review of their potentialities and limitations. Eur. Food Res. Technol. 2012, 234, 1-12. [CrossRef]

31. Kulkarni, P.; Loira, I.; Morata, A.; Tesfaye, W.; Gonzalez, M.; Suárez-Lepe, J.A. Wine maturation: Use of ultrasound treatment and non-Saccharomyces yeasts for accelerating ageing on lees in red wines. Wine Vitic. J. 2016, 31, 36 .

32. Cacciola, V.; Batllò, I.F.; Ferraretto, P.; Vincenzi, S.; Celotti, E. Study of the ultrasound effects on yeast lees lysis in winemaking. Eur. Food Res. Technol. 2013, 236, 311-317. [CrossRef]

33. González-Centeno, M.R.; Knoerzer, K.; Sabarez, H.; Simal, S.; Rosselló, C.; Femenia, A. Effect of acoustic frequency and power density on the aqueous ultrasonic-assisted extraction of grape pomace (Vitis vinifera L.). A response surface approach. Ultrason. Sonochem. 2014, 21, 2176-2184. [CrossRef]

34. Tao, Y.; Zhang, Z.; Sun, D.W. Kinetic modeling of ultrasound-assisted extraction of phenolic compounds from grape marc: Influence of acoustic energy density and temperature. Ultrason. Sonochem. 2014, 21, 1461-1469. [CrossRef] [PubMed]

35. Drosou, C.; Kyriakopoulou, K.; Bimpilas, A.; Tsimogiannis, D.; Krokida, M. A comparative study on different extraction techniques to recover red grape pomace polyphenols from vinification byproducts. Ind. Crops Prod. 2015, 75, 141-149. [CrossRef]

36. Piñeiro, Z.; Marrufo-Curtido, A.; Serrano, M.J.; Palma, M. Ultrasound-assisted extraction of stilbenes from grape canes. Molecules 2016, 21, 784. [CrossRef] [PubMed]

37. Martín, J.F.G.; Sun, D.W. Ultrasound and electric fields as novel techniques for assisting the wine ageing process: The state-of-the-art research. Trends Food Sci. Technol. 2013, 33, 40-53. [CrossRef]

38. Zhang, Q.A.; Shen, Y.; Fan, X.H.; Martín, J.F.G.; Wang, X.; Song, Y. Free radical generation induced by ultrasound in red wine and model wine: An EPR spin-trapping study. Ultrason. Sonochem. 2015, 27, 96-101. [CrossRef] [PubMed]

39. Lukic, K.; Brnčić, M.; Curko, N.; Tomašević, M.; Valinger, D.; Denoya, G.; Barba, J.; Ganić, K.; Zhang, Q.A.; Wang, T.T. Effects of high power ultrasound treatments on the phenolic, chromatic and aroma composition of young and aged red wine. Ultrason. Sonochem. 2019, 59, 104725. [CrossRef] 
40. Zhang, Q.A.; Wang, T.T. Effect of ultrasound irradiation on the evolution of color properties and major phenolic compounds in wine during storage. Food Chem. 2017, 234, 372-380. [CrossRef]

41. Commission Regulation (EEC), No. 2676/90 determining Community methods for the analysis of wines. Off. J. Eur. Communities 1999, L272, 1-192. Available online: http://data.europa.eu/eli/reg/1990/2676/oj (accessed on 12 March 2020).

42. Boulton, R. The copigmentation of anthocyanins and its role in the color of red wine: A critical review. Am. J. Enol. Vitic. 2001, 52, 67-87.

43. Ribéreau-Gayon, P.; Dubourdieu, D.; Donèche, B.; Lonvaud, A. (Eds.) The Microbiology of Wine and Vinifications. In Handbook of Enology, 2nd ed.; John Wiley \& Sons: West Sussex, UK, 2006.

44. Smith, P.A. Precipitation of tannin with methyl cellulose allows tannin quantification in grape and wine samples. Technical Review. AWRI Adel. Aust. 2005, 158, 3-7.

45. Busse-Valverde, N.; Gomez-Plaza, E.; Lopez-Roca, J.M.; Gil-Munoz, R.; Fernandez-Fernandez, J.I.; Bautista-Ortin, A.B. Effect of different enological practices on skin and seed proanthocyanidins in three varietal wines. J. Agric. Food Chem. 2010, 58, 11333-11339. [CrossRef]

46. Pastor del Rio, J.L.; Kennedy, J.A. Development of proanthocyanidins in Vitis vinifera L. cv. Pinot noir grapes and extraction into wine. Am. J. Enol. Vitic. 2006, 57, 125-132.

47. Gómez-Plaza, E.; Mestre-Ortuño, L.; Ruiz-García, Y.; Fernández-Fernández, J.I.; López-Roca, J.M. Effect of benzothiadiazole and methyl jasmonate on the volatile compound composition of Vitis vinifera L. Monastrell grapes and wines. Am. J. Enol. Vitic. 2012, 63, 394-401. [CrossRef]

48. Cortell, J.M.; Halbleib, M.; Gallagher, A.V.; Righetti, T.L.; Kennedy, J.A. Influence of vine vigor on grape (Vitis vinifera L. cv. Pinot Noir) anthocyanins. 1. Anthocyanin concentration and composition in fruit. J. Agric. Food Chem. 2007, 55, 6575-6584. [CrossRef] [PubMed]

49. Hodson, G.; Wilkes, E.; Azevedo, S.; Battaglene, T. Methanol in wine. BIO Web Conf. 2017, 9, 02028. [CrossRef]

50. Zhang, Q.A.; Shen, Y.; Fan, X.H.; García Martín, J.F. Preliminary study of the effect of ultrasound on physicochemical properties of red wine. CyTA J. Food. 2016, 14, 55-64. [CrossRef]

51. Peinado, R.A.; Moreno, J.J.; Maestre, O.; Ortega, J.M.; Medina, M.; Mauricio, J.C. Gluconic acid consumption in wines by Schizosaccharomyces pombe and its effect on the concentrations of major volatile compounds and polyols. J. Agric. Food Chem. 2004, 52, 493-497. [CrossRef]

52. Aleixandre-Tudo, J.L.; Lizama, V.; Alvarez, I.; Nieuwoudt, H.; García, M.J.; Aleixandre, J.L.; du Toit, W.J. Effect of acetaldehyde addition on the phenolic substances and volatile compounds of red Tempranillo wines. Aust. J. Grape Wine Res. 2015, 22, 205-214. [CrossRef]

53. Del Torno-de Román, L.; Alonso-Lomillo, M.A.; Domínguez-Renedo, O.; Arcos-Martínez, M.J. Gluconic acid determination in wine by electrochemical biosensing. Sens. Actuators B Chem. 2013, 176, 858-862. [CrossRef]

54. Picariello, L.; Gambuti, A.; Picariello, B.; Moio, L. Evolution of pigments, tannins and acetaldehyde during forced oxidation of red wine: Effect of tannins addition. LWT Food Sci. Technol. 2017, 77, 370-375. [CrossRef]

55. Bautista-Ortín, A.B.; Fernández-Fernández, J.I.; López-Roca, J.M.; Gómez-Plaza, E. The effect of grape ripening stage on red wine color. OENO One 2006, 40, 15-24. [CrossRef]

56. Pérez-Magariño, S.; González-San José, M.L. Polyphenols and colour variability of red wines made from grapes harvested at different ripeness grade. Food Chem. 2006, 96, 197-208. [CrossRef]

57. Ferraretto, P.; Celotti, E. Preliminary study of the effects of ultrasound on red wine polyphenols. CyTA J. Food. 2016, 14, 529-535. [CrossRef]

58. Roman, T.; Tonidandel, L.; Nicolini, G.; Bellantuono, E.; Barp, L.; Larcher, R.; Celotti, E. Evidence of the possible interaction between ultrasound and thiol precursors. Foods 2020, 9, 104. [CrossRef] [PubMed]

59. Zhang, Q.A.; Xu, B.W.; Chen, B.Y.; Zhao, W.Q.; Xue, C.H. Ultrasound as an effective technique to reduce higher alcohols of wines and its influencing mechanism investigation by employing a model wine. Ultrason. Sonochem. 2020, 61, 104813. [CrossRef] [PubMed]

60. Zhao, T.; Wu, J.; Meng, J.; Shi, P.; Fang, Y.; Zhang, Z.; Sun, X. Harvesting at the Right Time: Maturity and its Effects on the Aromatic Characteristics of Cabernet Sauvignon Wine. Molecules 2019, 24, 2777. [CrossRef]

61. Dunlevy, J.D.; Kalua, C.M.; Keyzers, R.A.; Boss, P.K. The production of flavour \& aroma compounds in grape berries. In Grapevine Molecular Physiology \& Biotechnology, 3rd ed.; Markus Keller, Ed.; Springer: Dordrecht, The Netherlands, 2009; pp. 293-340. [CrossRef] 
62. Morena Luna, L.H.; Reynolds, A.G.; Di Profio, F.A.; Zhang, L.; Kotsaki, E. Crop level and harvest date impact on four Ontario wine grape cultivars. II. Wine aroma compounds and sensory analysis. S. Afr. J. Enol. Vitic. 2018, 39, 246-270. [CrossRef]

63. Bindon, K.; Varela, C.; Kennedy, J.; Holt, H.; Herderich, M. Relationships between harvest time and wine composition in Vitis vinifera L. cv. Cabernet Sauvignon 1. Grape and wine chemistry. Food Chem. 2013, 138, 1696-1705. [CrossRef]

64. Bakker, J.; Clarke, R.J. Wine: Flavour Chemistry, 2nd ed.; John Wiley \& Sons: Hoboken, NJ, USA, 2011.

65. Escudero, A.; Arias, I.; Lacau, B.; Astraín, J.; Barón, C.; Fernandez-Zurbano, P.; Ferreira, V. Effects of vineyard 'potential' and grape maturation on the aroma-volatile profile of Grenache wines. OENO One 2019, 53. [CrossRef]

66. Restrepo, S.; Espinoza, L.; Ceballos, A.; Urtubia, A. Production of Fatty Acid Content during Alcoholic Wine Fermentation under Selected Temperature and Aeration Conditions. Am. J. Enol. Vitic. 2019, 70, 169-176. [CrossRef]

67. Peng, C.T.; Wen, Y.; Tao, Y.S.; Lan, Y.Y. Modulating the formation of Meili wine aroma by prefermentative freezing process. J. Agric. Food Chem. 2013, 61, 1542-1553. [CrossRef] [PubMed]

68. Ćurko, N.; Kelšin, K.; Jambrak, A.; Tomašević, M.; Gracin, L.; Poturica, V.; Ružman, E.; Ganić, K. The effect of high power ultrasound on phenolic composition, chromatic characteristics, and aroma compounds of red wines. Croat. J. Food Sci. Technol. 2017, 9, 136-144.

69. García, J.F.; Zhang, Q.; Feng, C. Ultrasounds for accelerating the wine ageing process from physicochemical point of view. In Applications of Ultrasound in the Beverage Industry; Nova Sciences: Hauppauge, NY, USA; New York, NY, USA, 2016; pp. 147-165.

70. Noble, A. Bitterness in wine. Physiol. Behav. 1994, 56, 1251-1255. [CrossRef]

71. Cretin, B.; Dubourdieau, D.; Marchal, A. Influence of ethanol content on sweetness and bitterness perception in dry wines. LWT 2018, 87, 61-66. [CrossRef]

72. Casassa, L.F.; Beaver, C.W.; Mireles, M.; Larsen, R.C.; Hopfer, H.; Heymann, H.; Harbertson, J.F. Influence of fruit maturity, maceration length, and ethanol amount on chemical and sensory properties of Merlot wines. Am. J. Enol. Vitic. 2013, 64, 437-449. [CrossRef] 